\title{
Unknown Compositions by Johann Alois Lamb in Lubiąż. A Contribution to the Composer's Biography
}

\author{
Ewa Hauptman-Fischer
}

In recent years research on small music collections has been undertaken with growing interest, where the objects of attention are parish, church, and school-related music manuscript collections that have until recently remained outside the main current of musicological study. Interestingly, the object of scholarly inquiry is constituted by the music culture of those centres in which music manuscripts have not survived, or are extant to a limited degree. Its effect is often a detailed knowledge about the music culture of a given place, documented by extra music and archival sources. An example is provided by the biography of composer Johann Alois Lamb, shown in the background of the music culture in the Czech town of Vrchlabí. ${ }^{1}$ Studies conducted in the Music Department at the University of Warsaw Library (BUW) on the music manuscripts from the Cistercian monastery in Lubiąż ${ }^{2}$ could serve to complete the research to-date on the life and output of this composer.

1 Jakub Michl: Johann Alois Lamb - život a dílo vrchlabského kantora. Část první, Hudební věda 51, 2014, nr. 3-4, pp. 303-322. I wish to sincerely thank the author for making his doctoral dissertation available before its publication.

2 They are currently kept at the Music Department of the University of Warsaw Library. Studies on the music manuscripts from monasteries, including the Lubiąż collection, are being conducted within the project "The Cultural Legacy of the Monasteries Resolved in the former Polish Commonwealth and in Silesia during 18th and 19th c.: the Fate, Importance, and Inventory" (11H 11 021280), realized through the "National Program for Humanities Development" program of the Ministry of Sciences, Letters, and Higher Education in the years 2012-2016. For a discussion of the research, see Ewa Hauptman-Fischer: Muzykalia poklasztorne w Gabinecie Zbiorów Muzycznych Biblioteki Uniwersyteckiej w Warszawie - identyfikacja i inwentaryzacja [Monastery Musical Manuscripts held at the Music Department of University of Warsaw Library: Identification and Inventorization], Hereditas Monasteriorum 1, 2012, pp. 438-441. The present author is also preparing a doctoral dissertation about the Cistercian music manuscripts in the BUW collections. 


\section{Johann Alois Lamb in Vrchlabí}

The birthdate of Czech cantor Johann Alois Lamb is unknown, except that it fell in the mid-1750s. The documents from the last years of his life indicate three possible dates of birth: 1752 , 1754 , or $1756 .{ }^{3}$ We can thus accept that he was born around 1755 , probably in Vrchlabí. This is also where he died on November 27, 1820. The major part of his lifetime was spent in the same place, where he worked as a teacher and director of a public school, served as cantor in a local church, and belonged to the local theatrical society. We know that he was an active musician performing on the violin and singing vocal parts in theatrical plays staged in Vrchlabí. The life of Johann Alois Lamb has been recreated and described in detail owing to scrupulous archival studies by the author of the mentioned monograph. Unfortunately, no documents associated with Lamb survive from before 1776, when he was married in Vrchlabí, a fact noted in registry books. ${ }^{4}$ In 1777 , when Lamb had his oldest daughter baptized, records referred to him as 'Inquilinus Musicus', ${ }^{5}$ which indicates two important facts: Lamb worked as a musician, and probably settled in the city in the recent past, now continuing to be perceived as a person from outside. In 1779, Lamb underwent a six-week course in Prague ending with an examination in reading, writing, orthography, counting, and religion, ${ }^{6}$ thus obtaining the rights to practice the profession of teacher at a trivium municipal school which he later fulfilled. The extant documents allow us to draw two important conclusions: Lamb studied music in his childhood and achieved a significant level of proficiency in playing an instrument and in singing. $\mathrm{He}$ also had a basic education, which enabled him to pass his exams and assume teaching and directorial duties at a local school. He gained these skills and initially developed them beyond his place of residence, unknown until now. The solution to the latter riddle engaging Czech researchers is brought this time not by archival sources, but by music manuscripts kept in a distant Cistercian monastery.

3 Jakub Michl: Johann Alois Lamb - život a dílo vrchlabského kantora. Část první, Hudební věda 51, 2014, nr. 3-4, p. 305.

4 October 2, 1776: "Copulans: Josephus Meisner Capell[anus] / Lamb Joannes Honestus Juvenis civis fabri Ferrarius Filius + Joannis Lamb civis fabri Serrarij Cum Apollonia filia Francisci Maij civiLanionis [!] Albipol." Quoted after: Ibidem, p. 306.

5 “Lamb Joannes, Inquilinus Musicus”, quoted after: Ibidem, p. 306.

6 For a facsimile of the document, see: Ibidem, p. 306. 


\section{Sources kept in Lubiąż}

In the Lubiąż collections four manuscripts have survived with Joannes Lamb as scriptor ${ }^{7}$ (see Table 1). The first source was set down in 1750 by a copyist unknown by name. ${ }^{8}$ In 1766, Joannes Lamb added another vocal part to the manuscript containing the same music, but a different text.

Fig. 1: Johann Lamb's signature, call no. BUW, RM 4457/10

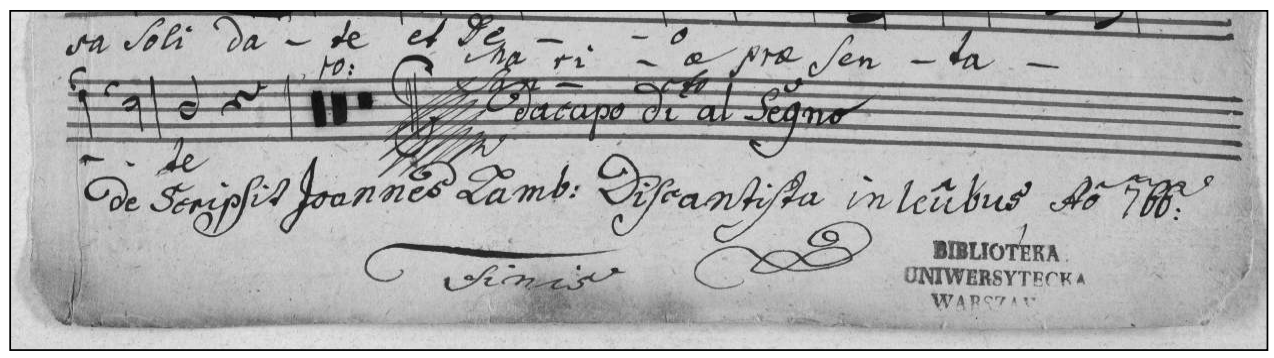

This is also a very interesting example of the life of a music source. In this manuscript, there are three various texts destined for different moments of the liturgical year. The varied ducti of writing indicate that the particular texts were inscribed successively right up to 1766, when the need for adding yet another fourth text required the preparation of a second copy for the vocal part. In the first (earlier) soprano part, the following texts can be found: 1. Marian hymn Salve virgo florens, 2. Hymn to the Holy Spirit Beata nobis gaudia, 3. Hymn for the feast of St. Hedwig Fortem virili pectore. The copy prepared by Lamb in 1766 includes an unidentified text, Inter laetantium plausus diem solemnem. It is no surprise that the music set in the manuscript was considered beautiful and continued to be used 16 years later. The composition was authored by Johann Adolf Hasse (1699-1783), who was then at the height of his fame. It is a contrafactum of the aria Il ciel mi vuole oppresso from the opera Semiramide riconosciuta, composed in 1744.

Two further signatures by Johann Lamb are dated $1767,{ }^{9}$ while the last two are found in a manuscript dated $1768^{10}$ (see Fig. 2 and 3).

7 Ewa Hauptman-Fischer - Katarzyna Spurgjasz: Sprawozdanie z inwentaryzacji muzykaliów poklasztornych w Gabinecie Zbiorów Muzycznych BUW w okresie 1 XI 2013-30 IV 2014 [Report on the Inventarization of Musical Manuscripts from Monasteries at the BUW Music Department in the Period: Nov. 1, 2013-Apr. 30, 2014, Hereditas Monasteriorum 4, 2014, pp. 487-488.

8 University of Warsaw Library (BUW), Music Department (the present location of all musical manuscripts described in the article) RM 4457/10.

9 RM 4133: "Descripsit Joannes Lamb discantista Lubae. Anno 1767" and RM 4854; here Lamb signs his name twice: "Descripsit Joannes Lamb Discantista in Lubae" and "Descripsit Joannes Lamb Discantista Lubae. Anno Domini 1767”.

10 RM 4631: "Descripsit Joannes Lamb discantista Lubae. 1768" and "Descripsit Joannes Lamb discantista Lubae. Principista 1768”. 
Fig. 2: Signature by Johann Lamb, call no. BUW, RM 4631

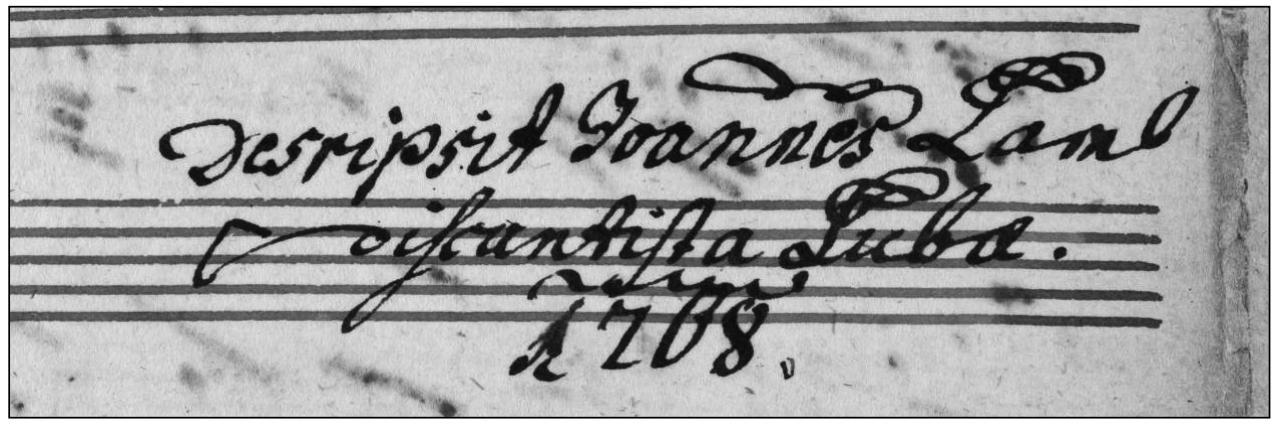

Lamb signed all the manuscripts with the Latin version of his forename, which was definitely a common practice in monastery circles. Never did he use his second name in a signature, whether in the Latin (Aloysius) or German version (Aloys or Alois). We should emphasize that in the surviving records and documents associated with the Czech composer Johann Alois Lamb, his name also rarely appears in full. We find Lamb's two forenames only in the official document which define his right to practice the teaching profession, ${ }^{11}$ and in surviving autographs by the composer. ${ }^{12}$ The quoted marriage certificate uses the name "Joannes Lamb", ${ }^{13}$ as does the baptism certificate of his oldest daughter. ${ }^{14}$ This is also how the Lubiąż manuscripts copied by Lamb are signed. The dates retained in the manuscripts testify to Joannes Lamb's activity as scriptor in Lubiąż during the years 1766-1768..$^{15}$ These manuscripts come from the local monastic church, which we know from the inscription "Chori Lub[ensis]" ${ }^{16}$ that is characteristic of this collection, and the choir regent's monogram in the manuscript RM 4854: "p[ro] Choro Lub[ensi] Pr[ocuravit] P[ater] M[aurus] p[ro] t[empore] R[egens] C[hori] 1768.”. ${ }^{17}$ During this

\footnotetext{
11 “Johann Aloysius Lamb", cf. footnote 6.

12 "Lamb Joann Aloysius", cf. Ibidem, p. 318.

13 Cf. footnote 2.

14 Cf. footnote 5.

15 According to the available documents, he wrote down the first source when he was between 10-14 years old.

16 For a discussion of the provenance notes regarding the collections, see: Sprawozdanie z inwentaryzacji muzykaliów poklasztornych w Gabinecie Zbiorów Muzycznych BUW w okresie 1 XI 2013-30 IV 2014, Hereditas Monasteriorum 4, 2014, pp. 486-487.

17 Maurus Brendtwein (1719-1783), regens chori, cf. Rudolf Walter: Leubus Zisterzienserkloster, [in:] L. Hoffmann-Erbrecht (Hg.), Schlesisches Musiklexikon, (Augsburg 2001), p. 421. Maurus Brandtwein filled the function of regent in the years 1755-1769, which is testified by inscriptions on the title pages of 13 manuscripts, cf. RM 4833, RM 5569, RM 4445/1, RM 5424, RM 4349, RM 4366, RM 4862, RM 4734, RM 4534, RM 4403/1, RM 4761, RM 4854, RM 4995, RM 4672.
} 
time, Joannes Lamb is certain to have sung in the monastic ensemble as a descant. In 1768 he started to study, a fact we are informed of by the inscription "principista"18 (Fig. 3).

Fig. 3: Signature by Johann Lamb, call no. BUW, RM 4631

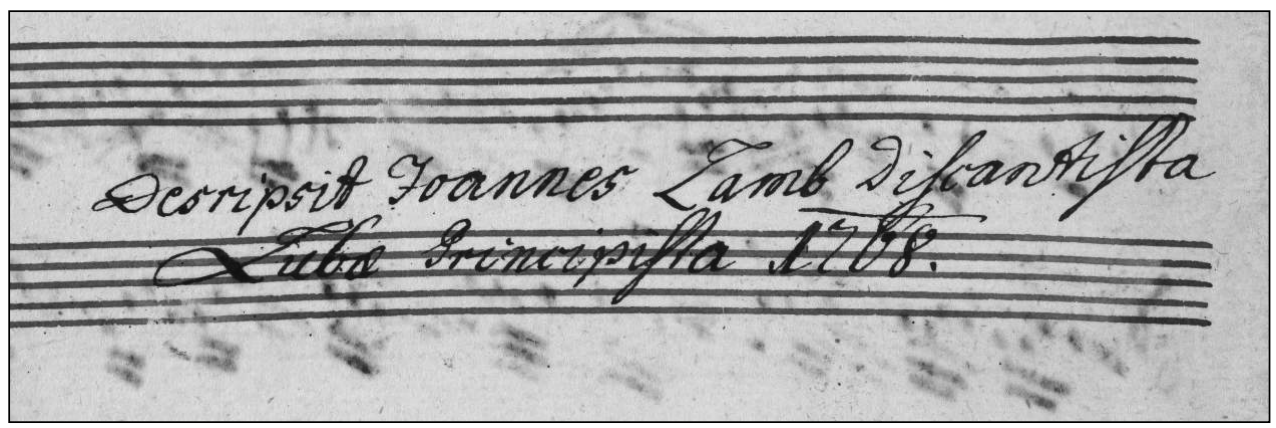

At this time in Lubiąż, there was an elementary school that was founded after the Thirty Years' War by St. Jacob's Parish, ${ }^{19}$ which belonged to the monastery. As from 1765, future teachers were also trained in Lubiąz in the teacher seminary. ${ }^{20}$ It is difficult to establish today which of these schools Lamb began attending in 1768, since we do not know his birthdate, and consequently his age. According to documents obtained later, he was between 12 and 16 years old. A boy of this age could already be completing the gymnasium and beginning the next education stage. Until the end of his life, Johann Alois taught in the trivium school. If we accept the hypothesis that Joannes Lamb is identical to the composer Lamb active in Vrchlabí, we could surmise that he was trained at the Lubiąz teacher seminary, and after moving to Vrchlabí validated his abilities through a state examination. ${ }^{21}$ It is certain that Lamb completed his studies in Lubiąż, and hence most likely stayed there in the years following 1768.

\section{RM 4631.}

19 This was a church located in close proximity to the monastery, destined mainly for its lay workers and their families with pastoral care and eventually extended by the Cistercians, cf. Ibidem, p. 421.

20 Ibidem, p. 421, Jerzy Mrukwa: Wkład Jana Ignacego Felbigera w reformę szkolnictwa podstawowego w drugiej połowie XVIII w. [Jan Ignacy Felbiger's Contribution to the Reform of Primary Schooling in the First Half of the Eighteenth Century], in: Ślaskie Studia Historyczno-Teologiczne 13 [Silesian Historico-Theological Studies 13], 1980, p. 334.

${ }_{21}$ These are times in which reforms in elementary schooling are introduced both in Prussia and the Habsburg Monarchy. The author of both reforms was the Żagan abbot J. I. Felbiger, who first prepared the statutes for schooling in Prussia (1765) and later, at the invitation of Maria Theresa, travelled to Vienna and prepared a statute for schooling in the Habsburg Monarchy (1774). 


\section{Johann Alois Lamb's compositions in the collection of the Cistercians from Lubiąż}

In 1771, two Masses were written and signed in the first case ${ }^{22}$ with the name "Joa[nnes] Aloys[ius] Lamb." (Fig. 4), and in the second ${ }^{23}$ with "Joa[nnes] Aloys[ius] Lamboij" (Fig. 5). These are the composer's autographs. In both cases, the surname is preceded by the inscription "Auth[ore] et Posses[ore]". The indication of provenance from the monastery, "Chori Lubensis", was added by another hand, most likely after the manuscript's transfer to the local chapel ensemble. The titles reveal the original chronology of the sources: in the first source ${ }^{24}$ the title is "Sacrum" 25 , and in the second it is "Sacrum Novum" ${ }^{26}$. The Masses are destined for the feast of St. Joseph (celebrated on March 19) and the feast of St. Philip and St. Jacob the Apostles (celebrated on May 6) respectively. The Mass for the feast of St. Joseph is a complete setting of the ordinarium missae. The second Mass is comprised only of the Kyrie and Gloria (for a detailed list of parts with their instrumentation, see the appendix).

\section{Hypotheses and research perspectives}

The intent of this article is not a detailed music analysis of the surviving Masses, but their presentation in the context of hypotheses connected with their authorship and place of origin. The sources were studied in depth and compared to transferences of Johann Alois Lamb's works known to-date in relation to, for instance, the similarity of form, texture, and instrumentation. However, it seems highly probable that these works were written by the composer we are discussing. Speaking in favour of this possibility is the convergence of the used forenames and the surname variant. Lamb's works were copied for the needs of other collections during his lifetime. They were signed with his surname, which often appears in various forms, e.g. Lambini and Lamboni, but also Lamp and Lamm. ${ }^{27}$ When creating the catalogue of the composer's works, Jakub Michl divided the sources signed with a variant of the surname into two groups. He listed compositions having other transferences and whose authorship is certain in the composer's catalogue of works. He then brought together compositions signed only by a variant of the surname and annotated in other sources with an established authorship into the group of works unconfirmed by other sources. The latter's attribution is subject to change according to new discoveries

\footnotetext{
RM 4573.

RM 4574.

RM 4573.

This is a term characteristic for Silesia in reference to a Mass.

RM 4574.

27 Jakub Michl: Johann Alois Lamb v kontextu hudební kultury v Čechách 2. poloviny 18. století (Master's dissertation, Charles University in Prague, advisor doc. PhDr. Marta Ottlová,), Prague 2010, p. 53, pp. 85-105 (appendix includes the composer's catalogue of works).
} 
of subsequent transferences. The Lubiąż collection thus includes two Masses signed with the proper forenames, and in one case a variant of the surname, while in the other with the proper surname. The Mass in manuscript RM 4573 has its second transmission in the musical manuscripts collection of the Cistercians in Krzeszów. This copy is signed with the same surname variant as in the Lubiąz copy, and was made in the same year. ${ }^{28}$ If the attribution of the above-mentioned Masses could be successfully confirmed using other sources, the Cistercian manuscripts would increase the composer's output known to-date by two new works. They would also become the earliest-dated compositions by Johann Alois Lamb, confirming Jakub Michl's thesis that Lamb's compositional activity began in the $1770 \mathrm{~s} .{ }^{29}$ The presence of the earliest known transferences of works by Johann Alois Lamb in Lubiąż suggests the composer's ties with this location, which also confirms the thesis that Joannes Lamb, scriptor of the Cistercian manuscript, is identical to Johann Alois Lamb, active later in Vrchlabí. The above hypothesis may constitute an explanation for the lack of sources regarding the composer's life and activity in Vrchlabí before 1776. It also fills the gap in his biography: the composer seems to have spent his youth in the Cistercian monastery in Lubiąż, where he obtained his musical and elementary education that prepared him for the teaching profession.

When examining the surviving sources, my attention turned to manuscripts containing a characteristic error on the title page that were found in both collections. These are copies of the Motetto in $C .{ }^{30}$ Both identically, but incorrectly, state the composer's surname as "Masehek [beside:] Righini”. The Lubiąż manuscript is dated 1801, while Lamb's copy is undated; the chronology of the sources is thus unknown. However, it seems probable that one was a copy of the other. The last hypothesis thus concerns Lamb's contacts with Lubiąż which could have still been maintained. Research into further contacts between the centres would necessitate an in-depth analysis of the convergences in the repertoire, copyists, and watermarks.

28 R. Walter: MUSIKGESCHICHTE DES ZISTERZIENSERKLOSTERS GRÜSSAU. VON ANFANG DES 18. JAHRHUNDERTS BIS ZUR AUFHEBUNG IM JAHRE 1810, (Musik des Ostens, 15), Kassel - Bassel a.o. 1996, pp. 99, 242. It is not surprising that precisely this Mass was copied to Krzeszów (or was a gift from the composer). Beginning in 1669, a brotherhood of St. Joseph was active in Krzeszów that numbered tens of thousands of members. On the patron's day, several thousand pilgrims drew together from Silesia and Czech cities, including Vrchlabí. For a wider discussion of the cult of St. Joseph, see for example Father Tadeusz Fitych: Cystersi w Krzeszowie jako propagatorzy kultu św. Jóżefa na Śląsku w XVII i XVIII w. [Cistercians in Krzeszów as Propagators of the Cult of St. Joseph in Silesia during the 17th and 18th c.], Colloquium Salutis. Wroctawskie Studia Teologiczne 10 [Colloquium Salutis. Wrocław Theological Studies 10], 1978, pp. 121-146. In addition, the Krzeszów collections include a funeral Mass in E major signed with the name "Johann Lamb" and figuring in J. Michl's catalogue under number I/6, cf. R. Walter: MUSIKGESCHICHTE DES ZISTERZIENSERKLOSTERS GRÜSSAU, p. 241-242, J. Michl: Johann Alois Lamb v kontextu hudebni kultury, p. 90. Ibidem, p. 54.

30 Lubiąż manuscript, call no. RM 4859 and manuscript coll no. 19, prepared by Lamb and originating in Vrchlabí, cf. J. Michl, Johann Alois Lamb, p. 318. 
The Music Department at the University of Warsaw Library holds sources other than those discussed above, also signed with the name in question. Only one composition can at present be unequivocally ascribed to the output of Johann Alois Lamb owing to a dissertation by Jakub Michl. It is the Litaniae Lauretanae, signed with the surname Lamm (RM 4575) and figuring under number II/ $2^{31}$ in the composer's catalogue of works. The remaining manuscripts are:

- Regina caeli in C, author: Lamb (RM 8064),

- Missa in C, author: Lamb (RM 5890) - copy made in 1800, from the monastery of the regular canons in Wrocław,

- III Offertorium de Tempore, author: Lamb (RM 7429),

- Offertorium Eja Sion Gaude, author: Lamp (RM 8000).

In addition, one of the anonymous Masses dedicated to the abbess of the Cistercian monastery in Trzebnica, Bernarda Paczyńska, ${ }^{32}$ has two concordances in other collections. The same Mass, signed with the surname Lamm, is found in the Pauline Fathers monastery in Częstochowa. ${ }^{33}$ An identical work ascribed to another composer, Koželuh, exists in our Wrocław Clarisses collection. ${ }^{34}$ I hope that further studies will enable the conclusive confirmation of the authorship of the above compositions and the verification of hypotheses posed in the present article. All doubts could be clarified not only through detailed archival inquiries in Silesia related in particular to the Cistercian monastery in Lubiąż, but also through studies on other music collections.

\footnotetext{
$31 \quad$ Idem, Johann Alois Lamb v kontextu, p. 91.

$32 \quad$ RM 4857.

33 Cf. RISM A/II: 300000701.

34 RM 4718, manuscript dated 1787.
} 


\section{Appendix: Johann Alois Lamb’s autographs from the Cistercian collection in Lubiąż}

\section{RM 4573:}

\section{Lamb, Johann Alois (c. 1755-1820)}

Mass, D major

[cover:] Sacrum | In honorem Sancti Josephi. | a | Canto, Alto, Tenore, Basso | Violino I $^{\text {mo }}$ | Violino $2^{\text {do }} \mid$ Oboa $1^{\text {ma }} \mid$ Oboa $2^{\text {da }} \mid$ Cornu $1^{\text {mo }} \mid$ Cornu $2^{\text {do }} \mid$ Flauto-Traversis 20 Ad Et incarnatus | con | Organo. Solo Laudamus | [inscribed at a later time: Chori Lubensis] | Authore et Possesor: | Joan: Aloys: L[-]b. | 177[-]

Manuscript (autograph), 1771, in Latin

Persons mentioned in source: Lamb, Joannes Aloysius - owner, author

90 leafs + cover, surviving parts: S (9), A (7), T (7), B (8), vl 1 (12), vl 2 (12), ob 1 (6), ob 2 (6), fl, 1 (1), fl 2 (1), cor 1 in D and clno 1 in C (4), cor 2 in D and clno 2 in C (4), org (11) Format: $28 \times 22,5 \mathrm{~cm}$, watermarks: 1 . [moon], 2. [six-armed star]

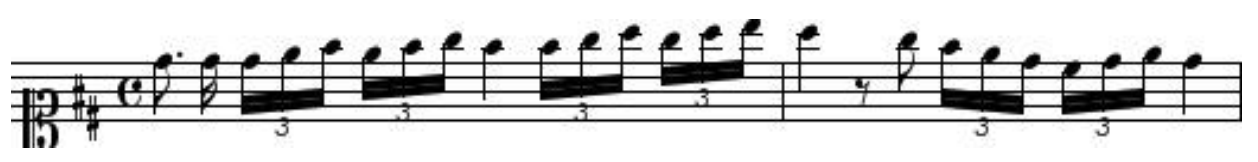

Kyrie eleison

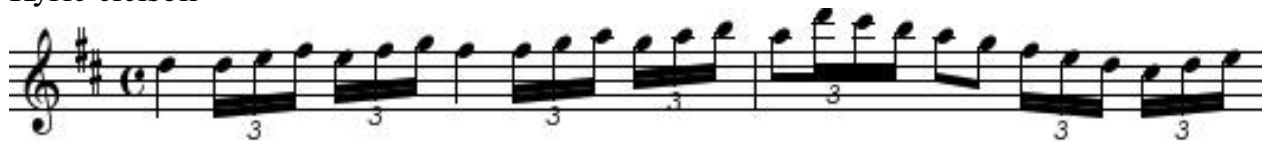

Parts of the composition:

1. Kyrie eleison, Allegro non molto, 4/4, D major, Coro: S, A, T, B, vl 1, 2, ob 1, 2, cor 1,2 , org

- Christe eleison, Andante, 3/4, G major, Solo: S, A, T, B, vl 1, 2, ob 1, 2, org

- Kyrie eleison (da capo)

2. Gloria, Allegro assai, 4/4, D major, Coro: S, A, T, B, vl 1, 2, ob 1, 2, cor 1, 2, org

- Et in terra, Tardissime, 2/2, D major, Coro: S, A, T, B, vl 1, 2, ob 1, 2, cor 1, 2, org

- Laudamus, Andantino, 2/4, B flat major, Solo: S, A, T, B, vl 1, 2, ob 1 solo, ob 2 solo, organo concerto.

- Gratias, Tardissime, 3/4, E flat major, T solo, vl 1, 2, org

- Domine, Allegro, 4/4, C major, Coro: S, A, T, B, vl 1, 2, ob 1, 2, clno 1, 2, org

- Qui tollis, Tarde, 3/4, c minor, S solo, Coro: A, T, B, vl 1, 2, org

- Quoniam, Andante, 2/4, G major, S solo, vl 1, 2, org

- Cum Sancto, Tarde, 3/4, D major, Coro: S, A, T, B, vl 1, 2, ob 1, 2, cor 1, 2, org

- In gloria, Allegro assai, 4/4, D major, Coro: S, A, T, B, vl 1, 2, ob 1, 2, cor 1, 2, org

3. Credo, Allegro, 3/4, D major, Coro: S, A, T, B, vl 1, 2, ob 1, 2, cor 1, 2, org

- Et incarnates est, Tarde, 4/4, B flat major, Solo: S, A, T, B, vl 1, 2, ob 1, 2, fl 1, 2, org

- Crucifixus est, Largissimo, 4/4, F major, Coro: S, A, T, B, vl 1, 2, org 
- Et resurrexit, Allegro, 4/4, D major, Coro: S, A, T, B, vl 1, 2, ob 1, 2, cor 1, 2, org 4. Sanctus, Tarde, 4/4, D major, Solo: S, A, Coro: T, B, vl 1, 2, ob 1, 2, cor 1, 2, org

- Pleni sunt, Allegro, 4/4, D major, Coro: S, A, T, B, vl 1, 2, ob 1, 2, cor 1, 2, org

5. Benedictus, Andante, 4/4, A major, S solo, vl 1 solo, org

6. Osanna, Allegro, 4/4, D major, Coro: S, A, T, B, vl 1, 2, ob 1, 2, cor 1, 2, org

7. Agnus Dei, Tarde, 4/4, D major, Solo: S, A, T, B, vl 1, 2, ob 1, 2, cor 1, 2, org

- Dona nobis, Allegro, 6/8, D major, S, A, T, B, vl 1, 2, cor 1, 2, org

Scoring: Solo: S, A, T, B, Choir: S, A, T, B, 2 vl, 2 fl, 2 ob, 2 cor, 2, clno, org

Number in Jakub Michl's thematic catalogue: none

Time destination: Sancti Josephi

Remarks: On the cover, a small white label with a handwritten inscription: "Mf 659". At the end of org: "O. A. M. D. G1. 1771", at the heading of org: "Omnia Ad Majorem Dei Gloriam" and the monogram "A:L" before the stave. Lower right corner of cover slightly damaged.

Concordances: R. Walter, p. $242^{35}$

Provenance: "Chori Lubensis" - Cistercian abbey in Lubiąż

Previous call numbers: [from Wrocław:] Mf 659

2. RM 4574:

Lamboij, Johann Alois (c. 1755-1820)

Mass (Kyrie and Gloria), F major

[cover:] Sacrum Novum | Pro | Festo Sanctorum Philippi et Jacobi | Apostolorum. | a | Canto, Alto | Tenore, Basso | Violino Primo | Violino Secundo | Oboa Prima | Oboa Secunda | Cornu Primo | Cornu Secundo | con | Organo. | Auth: et Posses: | Joa: Aloys: Lamboij. | [above, written by another hand: Chori Lubensis]

Manuscript (autograph), 1771, in Latin

Persons mentioned in source: Lamboij, Joannes Aloysius - possessor, author

55 leafs + cover, extant parts: S (4), A (4), T (4), B (4), vl solo (1), vl 1 (9), vl 2 (8), ob and fl 1 (4), ob. and fl 2 (4), cor and clno 1 (3), cor and clno 2 (3), org (6)

Format: $36 \times 23 \mathrm{~cm}$, watermarks: 1 . [crown] [below: W] ${ }^{36}, 2$. [crown] [below: W] ${ }^{37}, \mid$ TL [?]

35 R. Walter: Musikgeschichte des Zisterzienserklosters Grüssau, p. 242.

36 Cf. Kazimiera Maleczyńska: Dzieje starego papiernictwa ślaskiego [The Story of Old Silesian Papermaking], (Monografie Śląskie Ossolineum, IV) [Silesian Monographs from the Ossolineum, IV], Wrocław, Warsaw, Cracow 1961, p. 174.

37 Cf. Ibidem, p. 174. 


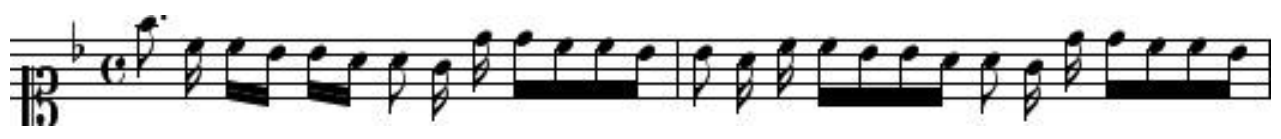

Kyrie eleison

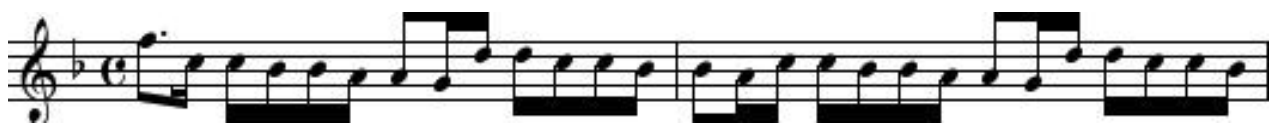

Parts of the composition:

1. Kyrie eleison, Allegro moderato, 4/4, F major, Coro: S, A, T, B, vl 1, 2, ob 1, 2, cor 1, 2

- Christe eleison, Andantino, 2/4, C major, Solo: S, A, T, B, vl 1, 2, ob 1, 2, org concertato

- Kyrie eleison, Allegro, 2/4, F major, Solo: S, A, T, B, Coro: S, A, T, B, vl 1, 2, ob 1,2 , cor 1, 2, org

2. Gloria, Allegro assai, 3/4, F major, Coro: S, A, T, B, vl 1, 2, ob 1, 2, cor 1, 2, org

- Et in terra, Tarde 2/2, B minor, Coro: S, A, T, B, vl 1, 2, ob 1, 2, org

- Laudamus, Andante, 2/4, D major, Solo: S, A, T, B, vl 1, 2, ob 1, 2, cor 1, 2, org

- Gratias, Tarde, 3/4, G major, T solo, vl 1, 2, fl 1, 2, org

- Domine, Andante, 4/4, C major, Solo: S, A, vl 1, 2, clno 1, 2, org

- Qui tollis, Tarde, 4/4, F major, Coro: S, A, T, B, vl solo, vl 1, 2, ob 1, 2, cor 1, 2, org

- Quoniam, Allegro, 4/4, D major, B solo, vl 1, 2, ob 1, 2, cor 1, 2, org

- Cum Sancto, Adagio, 3/4, F major, Coro: S, A, T, B, vl 1, 2, ob 1, 2, cor 1, 2, org

- In gloria, Allegro, 3/4, F major, Coro: S, A, T, B, vl 1, 2, ob 1, 2, cor 1, 2, org

Number in Jakub Michl's thematic catalogue: none

Time destination: Pro Festo Sanctorum Philippi et Jacobi Apostolorum.

Remarks: On the cover, a small white label with a handwritten inscription: "Mf 660". At the end of all parts: "O. A. M. D. GL", at the heading of org: "Omnia Ad Majorem Dei Gloriam" and the monogram "A:L" before the stave. At the end of ob 2: "O: A: M: D: G1. 1771 ". In the organo part: f. $2 \mathrm{v}, 3 \mathrm{v}, 7 \mathrm{r}$ remark: "pedale".

Concordances: none

Provenance: "Chori Lubensis" - Cistercian abbey in Lubiąż

Previous call numbers: [from Wrocław:] Mf 660 
Fig. 4: Title page of a Mass by J.A. Lamb, call no. BUW, RM 4573

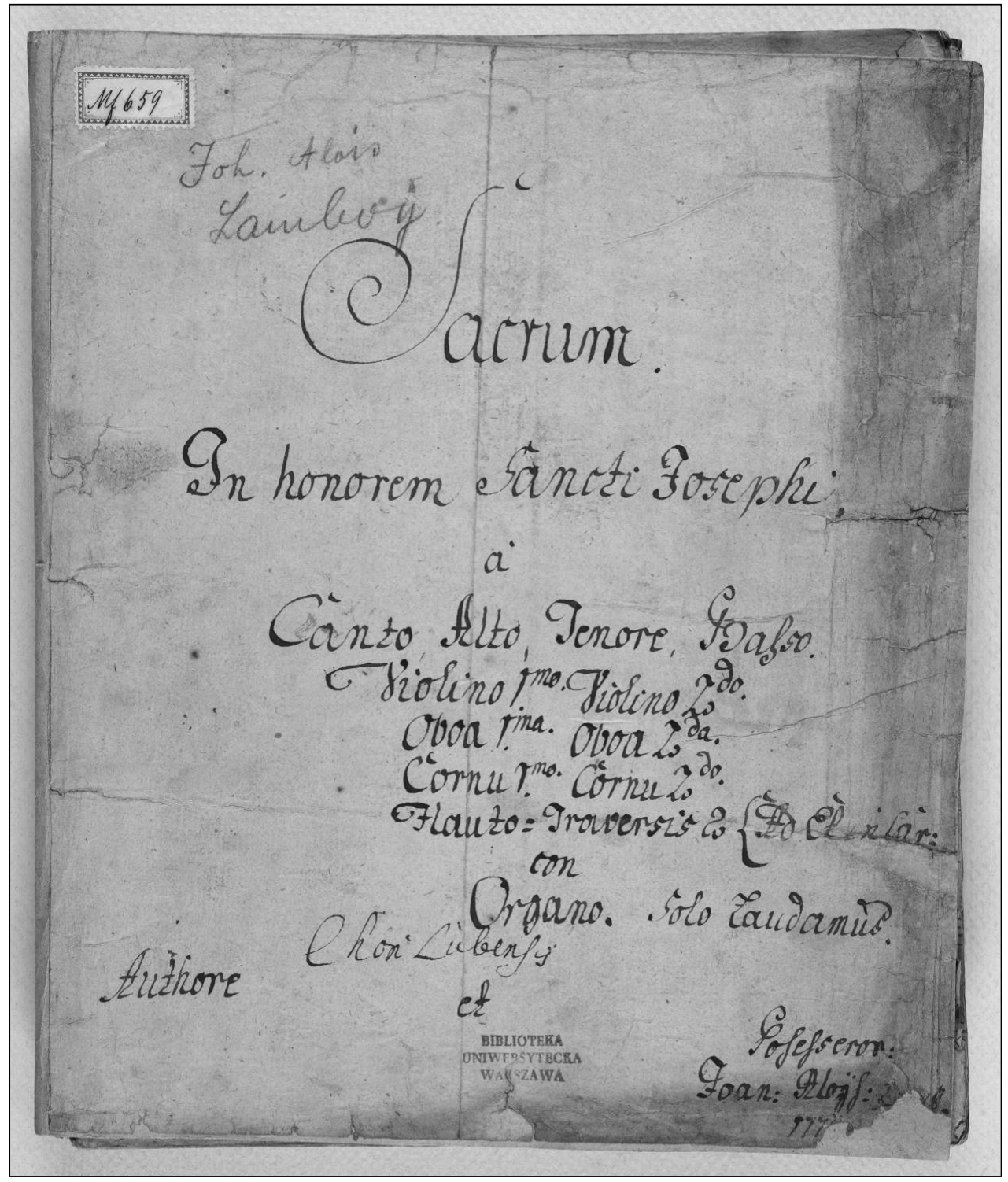


Fig. 5: Organ part from a Mass by J. A. Lamb, call no. BUW, RM 4573

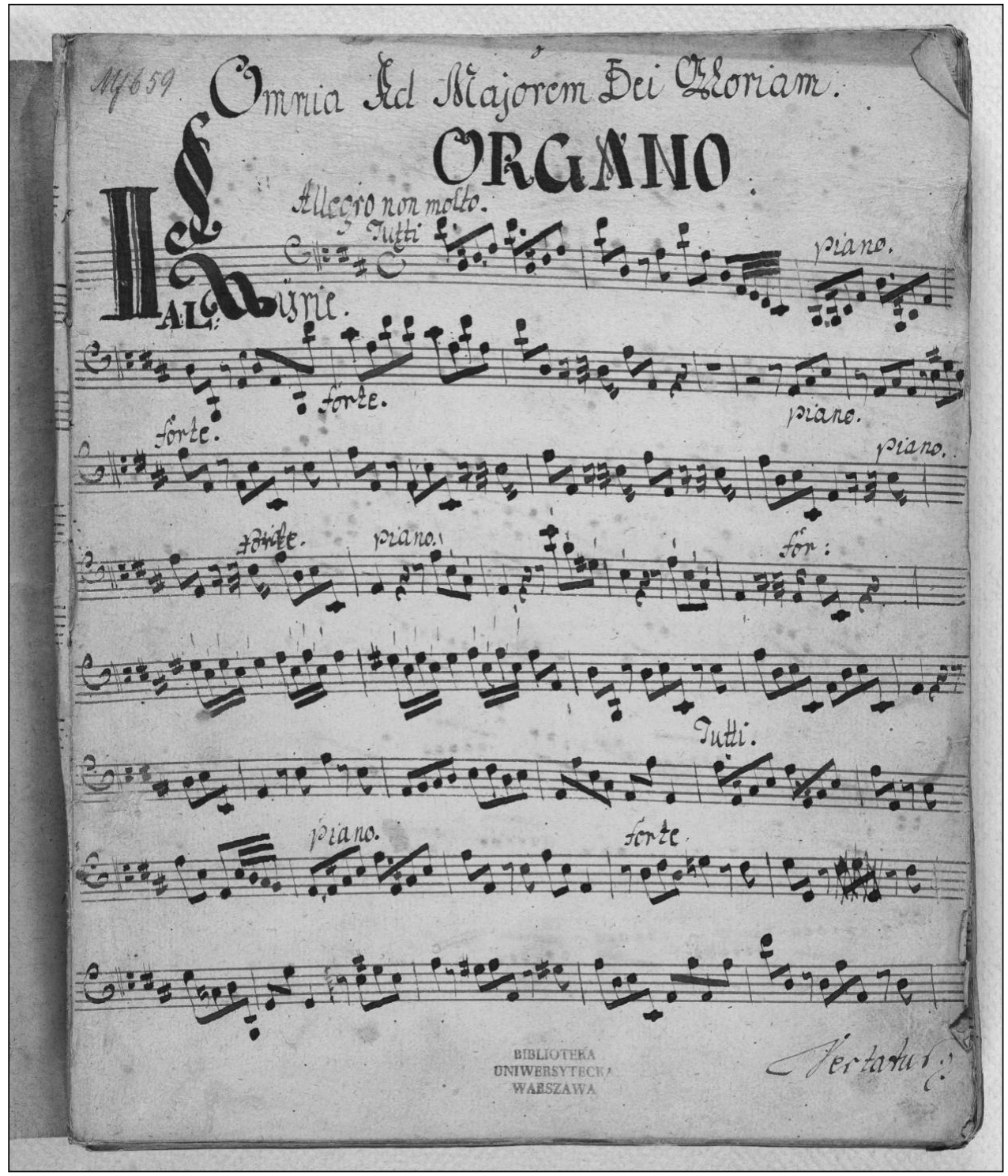


Fig. 6: Title page of a Mass by J. A. Lamb, call no. BUW, RM 4574

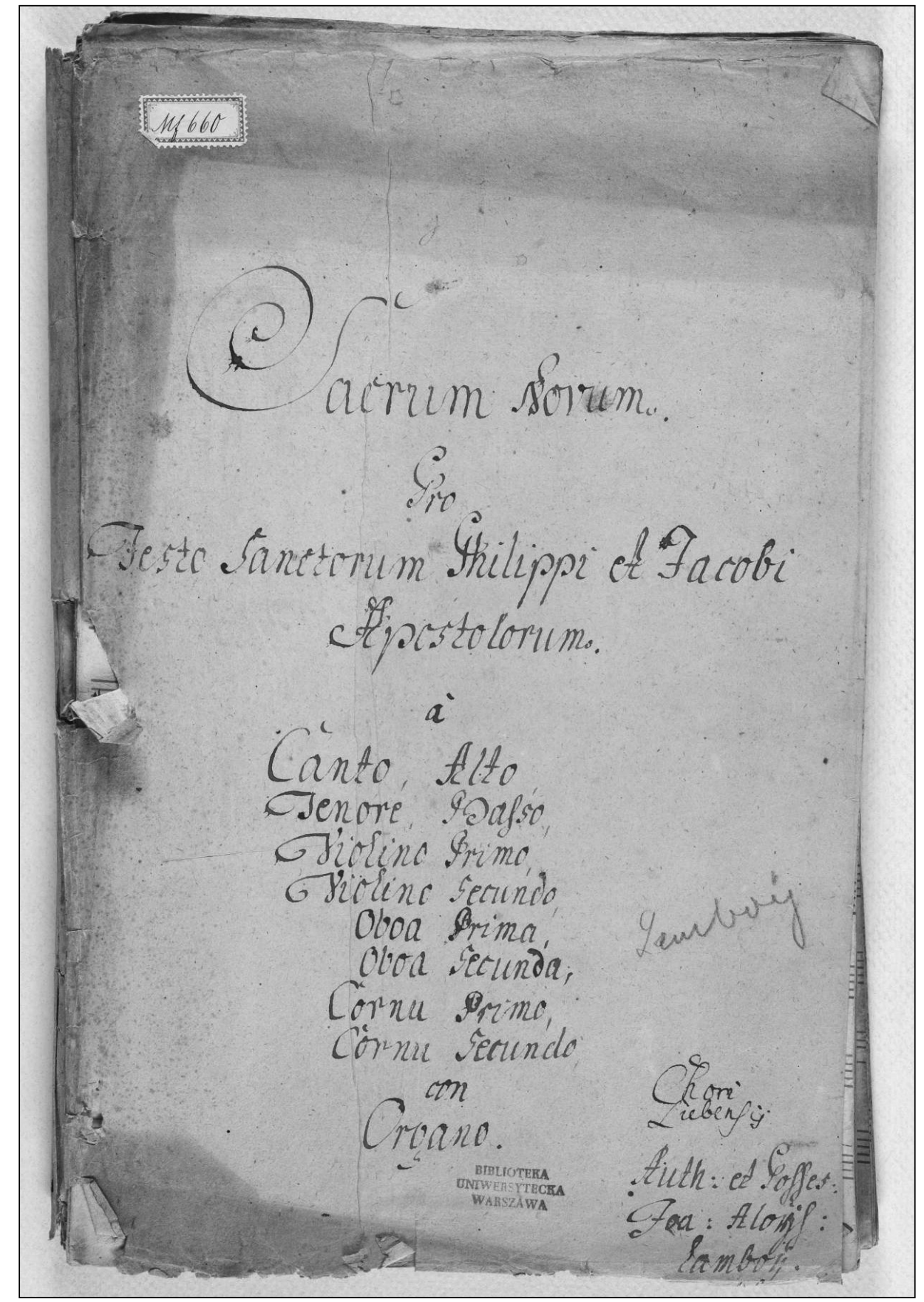


Table 1: List of the Lubiąż collection manuscripts prepared by Johann Lamb

\begin{tabular}{|c|c|c|c|}
\hline Call no. & Contents of title page & Physical description & $\begin{array}{c}\text { Scriptor's sig- } \\
\text { nature }\end{array}$ \\
\hline \begin{tabular}{|l|} 
RM \\
$4457 / 10$
\end{tabular} & $\begin{array}{l}\text { Num: } 2 \text {. | Aria ex B. [inscrip- } \\
\text { tion added to the right with } \\
\text { another hand: de Beata | Pro } \\
\text { Pentecoste | Servit etiam } \\
\text { pro Hymn. S. Hedwigis] | } \\
\text { à Voc. | Canto. | Violino } 1^{\circ} \text {. } \\
\text { | Violino } 2^{\text {do }} \text { | Viola. | Con } \\
\text { | Organo. | Auth. Sg }{ }^{\text {re }} \text { Hasse. } \\
\text { | C [inscribed later: hori] | } \\
\text { L [incribed later: ub:] 1750 }\end{array}$ & $\begin{array}{l}\text { Manuscript, 1750-1766, in Latin. } \\
10 \text { leafs + title page, extant parts: } \\
\mathrm{S}(1), \mathrm{S}(2), \mathrm{vl} 1 \text { (2), vl } 2 \text { (2), } \\
\text { vla (2), b (1). } \\
\text { Format: } 33 \times 21 \mathrm{~cm} \text {, watermarks: } \\
\text { 1. cover: Schweidnitz [below: } \\
\text { eagle] [below: } 1749 \text { ] I [boar], } \\
\text { 2. remaining parts: [crown with } \\
\text { cross] [below: S] }\end{array}$ & $\begin{array}{l}\text { S: "de Scripsit } \\
\text { Joannes Lamb: } \\
\text { Discantista } \\
\text { in leubus, Ad } \\
\text { 766:" }\end{array}$ \\
\hline RM 4133 & [No title page] & $\begin{array}{l}\text { Manuscript, 1767, in Latin. } \\
10 \text { leafs, extant parts: S (1), S (1), } \\
\text { vl 1 (1), vl 2 (1), vla (1), fl 1 } \\
\text { (1), fl } 2(1) \text {, cor } 1 \text { (1), cor } 2(1) \text {, } \\
\text { org (1). } \\
\text { Format: } 34 \times 22 \mathrm{~cm} \text {, watermarks: } \\
\text { 1. both parts S: W, } 2 \text {. vl 1, vla, fl } \\
\text { 1, fl 2: Schweidnitz [below: eagle] } \\
\text { [below: } 1749 \text { ], 3. vl 2, cor 1, cor 2, } \\
\text { org: [crown with cross] [below: S] }\end{array}$ & $\begin{array}{l}\text { S: “Descripsit } \\
\text { Joannes Lamb } \\
\text { discantista } \\
\text { Lubae. Anno } \\
\text { 1767" }\end{array}$ \\
\hline RM 4854 & $\begin{array}{l}\text { Missa seu Kyrie et Gloria } \\
\text { Imæ classis ex D. | a voc. } \\
\text { | Canto, Alto, | Tenore, Bas- } \\
\text { so, | Violinis 2bus [inscribed } \\
\text { to the right: Obois 2b[us] } \\
\text { non obligatis] | Alto Viola. | } \\
\text { Clarinis 2bus | con | Or- } \\
\text { gano. | Authore Dno. Ignatio } \\
\text { Rychlowsky | p. | Choro } \\
\text { Lub: Pr: | PM. p.t RC } 1768 \\
\end{array}$ & $\begin{array}{l}\text { Manuscript, 1767-1768, in Latin. } \\
35 \text { leafs + cover, extant parts: } \\
\text { S (4), A (2), T (2), B (2), vl } 1 \text { (6), } \\
\text { vl } 2 \text { (5), vla (4), ob } 1 \text { (2), ob } 2 \\
\text { (2), cor } 1 \text { (1), cor } 2 \text { (1), org (4), } \\
\text { Format: } 39 \times 26 \mathrm{~cm} \text {, watermarks: } \\
\text { 1. cover, S, T, vl 1, vl 2, vla, cor 1, } \\
\text { cor 2: [moon] | [star], 2. ob 1, 2: } \\
\text { Schweidnitz [below: eagle] | G } \\
\text { [below: CAMMERPAPIER] } \\
\end{array}$ & $\begin{array}{l}\text { S: "Descripsit } \\
\text { Joannes Lamb } \\
\text { Discantista in } \\
\text { Lubae" } \\
\text { A: "Descripsit } \\
\text { Joannes Lamb } \\
\text { Discantista } \\
\text { Lubae. Anno } \\
\text { Domini 1767" }\end{array}$ \\
\hline RM 4631 & $\begin{array}{l}\text { Num: | Ariæ } 2 \text { pro quavis } \\
\text { Festivitate ex B. | } 2^{\text {da }} \text { ex G. } \\
\mid \text { a | Tenore Solo. } 2^{\text {da }} \text { Canto } \\
\text { Solo | Violinis } 2^{\text {bus }} \mid \text { Alto } \\
\text { Viola | Lituis } 2^{\text {buss. }} \text { ex G } \\
\text { pro aria 2 } 2^{\text {da }} \mid \text { Con Organo | } \\
\text { Auth: R. D. Lohelly | Chori } \\
\text { Lubensis | } 1768\end{array}$ & $\begin{array}{l}\text { Manuscript, 1768, in Latin. } \\
11 \text { leafs + cover, extant parts: } \\
\text { S (1), T (1), vl } 1 \text { (2), vl } 2 \text { (2), vla } \\
\text { (2), cor } 1 \text { (1), cor } 2 \text { (1), org (1). } \\
\text { Format: } 36 \times 24 \text { cm, watermarks: } \\
\text { 1. cover: [eagle] | [crown] [be- } \\
\text { low: W], 2. vl 1, vl 2: Schweidnitz } \\
\text { [below: eagle] | G [below: CAM- } \\
\text { MERPAPIER], 3. S, cor 1: G, } 4 . \\
\text { cor 2, org: Schweidnitz [below: } \\
\text { CAMMERP] }\end{array}$ & $\begin{array}{l}\text { vl 1, f. 1r: "De- } \\
\text { scripsit Joannes } \\
\text { Lamb discantis- } \\
\text { ta Lubae. 1768", } \\
\text { f. 2r: "Descrip- } \\
\text { sit Joannes } \\
\text { Lamb discantis- } \\
\text { ta Lubae. Prin- } \\
\text { cipista } 1768 \text { " }\end{array}$ \\
\hline
\end{tabular}

Translated by Maksymilian Kapelański 


\title{
Unknown Compositions by Johann Alois Lamb in Lubiąż. A Contribution to the Composer's Biography
}

\begin{abstract}
The music manuscript collection of the Cistercians from Lubiąż, now held at the Music Department at the University of Warsaw Library, includes autographs of two heretofore unknown Masses by Johann Alois Lamb, a Czech composer active in the second half of the 18th century in Vrchlabí. These are also his earliest-dated compositions. The article presents hypotheses about the composer's early life. Based on an analysis of the manuscripts from Lubiąż signed with Lamb's name and sources referring to his life (described in a monograph by Jakub Michl), we can surmise that he spent his youth in the Cistercian monastery in Lubiąż, where he received his musical and elementary education. The article includes a discussion of all sources connected to Lamb from the Lubiąż Cistercian collection.
\end{abstract}

\section{Neznámé kompozice Johanna Aloise Lamba v Lubiąż. Př́spěvek k skladatelově biografii}

\begin{abstract}
Abstrakt
Sbírka hudebních rukopisů cisterciáků z Lubiąż, která je nyní uložena v Hudebním oddělení Knihovny Varšavské univerzity, obsahuje autografy dvou dosud neznámých mší Johanna Aloise Lamba, českého skladatele aktivního v druhé polovině 18. století ve Vrchlabí. Kompozice jsou z hlediska života skladatele jeho nejmladšími díly. Článek představuje hypotézy o raném období skladatelova života. Na základě analýzy rukopisů z Lubiąż podepsaných Lambovým jménem, stejně tak analýzy informačních zdrojů, které se vztahují k jeho životu (zpracováno v monografii Jakuba Michla), se můžeme domnívat, že Lamb strávil své mládí v cisterciáckém klášteře v Lubiąż, kde také získal hudební i základní vzdělání. Článek obsahuje přehled všech pramenů ze sbírky cisterciáků z Lubiąż spojených s působením J. A. Lamba.
\end{abstract}

\section{Key words}

Johann Alois Lamb; music collection; Lubiąż; Cistercians; Mass.

\section{Klíčová slova}

Johann Alois Lamb; hudební sbírka; Lubiąż; cisterciácký řád; mše. 